\title{
The Ethics Of Managing Short-Term Earnings: Business Managers And Business Students Rate Earnings Management Practices - Implications For Academia
}

Don E. Giacomino, Marquette University

Jodi L. Bellovary, Marquette University

Michael D. Akers, (Email: michael.akers@marquette.edu ), Marquette University

\begin{abstract}
In 1990, Bruns and Merchant surveyed the readership of the Harvard Business Review (HBR). Their survey asked HBR readers to rate the acceptability of earnings management practices. Prior to that study, researchers and accounting practitioners paid little attention to the morality of short-term earnings management. However, in the wake of highly publicized financial frauds and failures, the profession and academic journals have emphasized the importance of the concepts of earnings quality and earnings management. The Bruns and Merchant survey provided 13 earnings management situations and asked the HBR readers to rate the acceptability of those practices. In this study, we surveyed students and business managers to measure their perceptions about the morality of specific earnings management actions to determine if their perceptions are different from those of the HBR readers 15 years ago. This article also compares the results of our study with several other studies that used the Bruns \& Merchant instrument during the most recent 15 years. Based on our findings, we discuss implications for academia.
\end{abstract}

\section{INTRODUCTION}

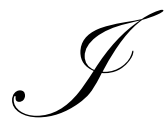

$\mathrm{n}$ the August 1990 issue of Management Accounting, William Bruns and Kenneth Merchant reported the results of their survey of the readership of the Harvard Business Review (HBR). The survey provided 13 earnings management situations that the authors had observed directly or indirectly and asked the HBR readers to rate the acceptability of those practices. Bruns and Merchant characterized the results as "frightening". They observed:

It seems that if a practice is not explicitly prohibited or is only a slight deviation from rules, it is an ethical practice regardless of who might be affected either by the practice or the information that flows from it. This means that anyone who uses information on short-term earnings is vulnerable to misinterpretation, manipulation, or deliberate deception.

We have no doubt that short-term earnings are being managed in many, if not all companies. Some of these earnings-management practices can be properly labeled as immoral and unethical.

Prior to the Bruns and Merchant study, researchers and accounting practitioners paid little attention to the morality of short-term earnings management. However, in the wake of highly publicized financial frauds and failures, the profession has emphasized the importance of the concepts of earnings quality and earnings 
management. For its 2002 Annual Meeting, the American Accounting Association chose the Quality of Earnings Project as its main theme. In turn, the academic journals have invited and published research articles that deal with earnings management (see Elias, 2002, 2004; Kim et al., 2003; Marquardt and Wiedman, 2004; Altamuro et al., 2005; Cheng and Warfield, 2005). Because of the recent emphasis on earnings management topics, we decided to survey students and business managers to measure their perceptions about the morality of specific earnings management actions to determine if their perceptions are different from those of the HBR readers 15 years ago. In addition, we test for differences between business students and managers and differences by gender and major.

The paper proceeds, in Section II, with a review of prior research studies beginning with the Bruns and Merchant study. Section III presents our study and compares our results with prior research findings. In Section IV, we discuss implications for academia, and in Section V, we provide our conclusions.

\section{PRIOR RESEARCH}

\section{The Bruns and Merchant Study}

Bruns and Merchant (1990) prepared a 13-action questionnaire that consisted of practices that the authors considered short-term earnings management. Such practices involved choice and timing of operating events and choice of timing of recognition of specific revenues and expenses. Respondents rated each practice on a five-point scale as follows:

$1=$ Ethical Practice

$2=$ Questionable Practice. I would not say anything to the person involved, but it makes me uncomfortable.

$3=$ Minor Infraction. The person should be warned not to engage in the practice again.

$4=$ Serious Infraction. The person should be severely reprimanded.

$5=$ Totally Unethical. The person should be fired.

The first page of the questionnaire informs the respondent that the survey consists of short descriptions of a variety of actions that individuals have taken. Some of these actions are clearly ethical. Others are judged by some or most people to be unethical, and the judgments as to the degree of severity of the infraction can vary widely. Respondents were to assume that the divisions referred to are part of a $\$ 1$ billion corporation, which has a JanuaryDecember fiscal year. Each division has annual sales of $\$ 100$ million, with annual before-tax operating profit of $\$ 12$ million.

Bruns and Merchant found that none of the practices were viewed unanimously as an ethical practice or as totally unethical. On average, the findings indicated that the direction of the impact (increase or decrease in EPS) was important, as was materiality. Reductions in earnings and smaller effects on earnings were judged more acceptable than increases in earnings and larger effects. The period affected (quarter vs. fiscal year) was also significant. Actions were rated less acceptable if they affected year-end numbers.

\section{Other Studies}

Seven studies (Merchant and Rockness, 1994; Rosenzweig and Fischer, 1994; Fischer and Rosenzweig, 1995; Clikeman et al., 2001; Elias, 2002, 2004; Guffey et al., 2004) subsequent to the Bruns and Merchant study have utilized the Bruns and Merchant survey discussed in the previous section. Table 1 lists the mean responses from four of these seven studies (three of the prior studies' mean responses were unavailable) and from our current study (for the 13 actions that correspond to the original Bruns and Merchant questionnaire. Full results for the current study will be discussed in detail later in the paper). Sample sizes of those studies range from 115 to 500 and consist of students, practicing accountants, and/or business managers. Table 1 also reports the average rating of the prior studies for each action and the average rating of the 13 actions for each study.

The mean of the responses of prior studies ranges from 1.09 (item 1, Clikeman et al., 2001) to 4.15 (item 13, Rosenzweig and Fischer, 1994). On average, the respondents of the prior studies rated actions rather 
consistently. The average ratings for the prior studies are 2.51, 2.58, 2.66, and 2.69. Respondents to prior studies rated:

- $\quad$ No actions as "Totally Unacceptable" (mean between 4.5 and 5.0).

- $\quad$ One action as a "Serious Infraction" (mean between 3.5 and 4.5).

- $\quad$ Six actions as a "Minor Infraction" (mean between 2.5 and 3.5).

- $\quad$ Four actions as a "Questionable Practice" (mean between 1.5 and 2.5).

- Two actions as an "Ethical Practice" (mean below 1.5).

Two studies, Clikeman and Henning (2000) and Kaplan (2001), focus on earnings management but do not utilize the Bruns and Merchant survey. Clikeman and Henning (2000) surveyed accounting and other business students when they were sophomores and again when they were seniors regarding earnings management. Students were given a short case which involved a financially distressed firm planning to delay normal maintenance expenditures to the next year in order to increase current year earnings. On a seven-point scale (where 1 is "strongly oppose postponement", 4 is "neutral", and 7 is "strongly support postponement"), the mean responses of sophomore accounting students and other business students were 3.79 and 3.68, respectively. The mean responses of the senior accounting students and other business students were 2.10 (decrease of 1.69) and 4.73 (increase of 1.05), respectively. Therefore, the accounting students became less accepting of the earnings management techniques from the sophomore to senior year, while the other business students became more accepting of the technique.

Kaplan (2001) provided MBA students with three separate earnings management scenarios. The scenarios involved an operating activity gain through deferral of discretionary expenses, an accounting activity gain by requesting an invoice from a consulting firm be delayed, and an accounting activity loss through an unnecessary increase in the obsolescence reserve. Students were randomly assigned to act as either a shareholder, another manager from the company unfamiliar with the manager in the case, or another manager from the company familiar with the manager in the case. Students were asked to judge the ethicality of the manager's decision, the likelihood that the company would suffer financially due to the decision, the seriousness of the consequences of the decision, and the fairness of the decision. Kaplan found that for the accounting gain/loss scenarios, the responses of students in the role of a manager were generally more unfavorable than those of the students in the role of a shareholder (except for the overall ethicality judgment). Evidence also suggested that the students in the role of the manager who knew the manager in the case judged the scenario more favorably than the students in the role of the manager who did not know the manager in the case. Kaplan found little evidence that role played a factor on judgments for the operating gain scenario.

Although previous earnings-management research has not focused on gender differences, gender differences have been examined in ethics and values studies. The results of this research have not been conclusive. Studies that have examined business students or business professionals (Akaah, 1989; Beltramini et al., 1984; Jones and Gautschi, 1988; Peterson et al., 1991) found that females were more concerned than males about ethical issues. While the findings from accounting studies (Sweeney, 1995; Cohen et.al., Eaton and Giacomino, 2000;) indicate that females are more moral, or have higher moral development, and tend to view questionable situations as less ethical than males, other studies (Giacomino and Akers, 1998; Akers and Giacomino, 1999; Akers and Giacomino, 2000; Akers and Eaton, 2003) suggest that, while there are some gender differences, there are more similarities than differences. These later findings are consistent with Fagenson's (1993) study that examined female and male entrepreneurs.

\section{Hypotheses}

Based on prior research findings, we make the following hypotheses for our study:

H1: There are no significant differences between females and males regarding the ethicality of the twenty earnings management actions.

H2: There are no significant differences between undergraduate students and business managers regarding the ethicality of the twenty earnings management actions. 
H3: There are no significant differences between accounting majors and other majors regarding the ethicality of the twenty earnings management actions.

\section{OUR STUDY}

\section{Sample}

We administered a survey questionnaire similar to the one used by Bruns and Merchant. We used the same rating system as Bruns and Merchant used in their study. Table 2 depicts our questionnaire, which consists of twenty actions related to ten earnings management practices.

The Bruns and Merchant study surveyed only business managers. Subsequent studies using the Bruns and Merchant questionnaire included students (Fischer and Rosenzweig, 1995; Clikeman et al., 2001; Elias, 2002, 2004; Guffey et al., 2004) and accounting practitioners and faculty (Elias 2002, 2004). Clikeman et al. (2001) surveyed students and made comparisons by culture (national origin) and gender. Our study adds to the literature not only by comparing views of business managers with those of undergraduate students using an updated sample, but also by testing for differences by major. Further, given the publicity of cases such as Enron and World Com, we wanted to determine if there have been changes in attitudes towards earnings management practices. Sufficient time has passed since these cases and the issuance of the Sarbanes-Oxley Act in 2002 that we might expect some change in the views on the morality of earnings management. Therefore, we surveyed two groups - undergraduate business students and business managers. The undergraduate students were enrolled in any of four accounting courses (Advanced Accounting, Auditing, Financial Statement Analysis, and Accounting Information Systems). The business managers were students in either an MBA program or an Executive MBA program. A breakdown of respondents by gender, level of education, and major is shown below.

\section{Demographic Data}

\begin{tabular}{|c|c|c|}
\hline Gender & Male & 171 \\
\hline & Female & 77 \\
\hline & No response & 1 \\
\hline & Total & \\
\hline & & 139 \\
\hline Level of Education & Undergraduate & 89 \\
\hline & MBA & 21 \\
\hline & Executive MBA & 249 \\
\hline & Total & 103 \\
\hline & & 14 \\
\hline Major & Accounting & 35 \\
\hline & Both & 90 \\
\hline & Finance & 7 \\
\hline & Other & 249 \\
\hline & No response & \\
\hline & Total & \\
\hline & & \\
\hline & &
\end{tabular}

\section{Results}

First, for each of the twenty practices, we computed the frequency distribution of responses, in total and by group (undergraduate student/business manager; male/female; accounting major/other major). Then, we computed the mean scores for each action in total and by group and we categorized the responses from "Totally Unacceptable" to "Ethical Practice" (Table 3 presents data for total respondents). Then, we used analysis of variance to measure differences between groups (Table 4). 
Based on the mean values of responses and the frequency distributions, we found that none of the twenty practices were rated as "Totally Unacceptable" (mean between 4.5 and 5.0) by any of the groups. We also found that:

- $\quad$ Only five of the twenty practices were rated as a "Serious Infraction" (mean between 3.5 and 4.5).

- $\quad$ Ten practices were rated as a "Minor Infraction" (mean between 2.5 and 3.5).

- $\quad$ Four practices were rated as a "Questionable Practice" (mean between 1.5 and 2.5).

- $\quad$ One action was rated as an "Ethical Practice" (mean below 1.5).

On the surface, these results seem to suggest that the respondents take a dim view of the acceptability of these practices, since only one action (paint ahead of schedule) was deemed as an "Ethical Practice". However, for the four practices that were viewed as "Questionable Practices", the respondents would not say anything to the person involved, although it made the respondent uncomfortable. In addition, for the ten practices categorized as minor infractions, the respondents believe that the person involved should be warned not to engage in the practice again. For the five practices categorized as "Serious Infractions", the respondents believe that the person involved should be severely reprimanded. Table 5 lists some additional interesting findings.

\section{Results of Hypotheses Tests}

Table 4 shows the results of testing for differences by gender, education level, and major. The greatest differences are by gender and the smallest differences are by education level.

\section{Hypothesis One (H1): Gender}

We found that females have a stricter view than males for 18 of the 20 short-term earnings management actions. For three of those 18 actions, the differences are significant at the .05 level. In the two cases where males had a stricter view, only one is significant. Therefore, hypothesis one that there are no significant differences between females and males regarding the ethicality of the twenty earnings management items is supported for 16 of the 20 actions. The four actions found to have significant differences are:

- $\quad$ Defer expenses to meet annual budget (Action 2b) - Females stricter

- $\quad$ Work overtime to reach budget target (Action $4 \mathrm{~b})$ - Females stricter

- $\quad$ Request deferred billing from supplier, \$500,000 (Action 8b) - Females stricter

- $\quad$ Raise return forecast from 22\% to 35\%, actual 35\% (Action 9b) - Males stricter

Hypothesis Two (H2): Education Level

We found that the undergraduate students had stricter views than the business managers (MBA and EMBA students) for 12 actions, two of which are significant. For the eight actions that the business managers had stricter views, none are significant. Therefore, hypothesis two that there are no significant differences between undergraduate students and business managers regarding the ethicality of the twenty earnings management items is supported for 18 of the 20 actions. The two actions found to have significant differences are:

- $\quad$ Defer expenses to meet quarterly budget (Action 2a) -undergraduate students stricter

- $\quad$ Defer expenses to meet annual budget (Action 2b) -undergraduate students stricter

\section{Hypothesis Three (H3): Major}

With respect to differences by major, accounting majors had stricter views on 14 of the 20 actions, two of which are significant. For the six actions where other majors had stricter views than accounting majors, one is significant. Based on these findings, hypothesis three that there are no differences between accounting majors and other business majors is supported for all but three of the 20 actions. The three actions found to have significant differences are: 
- $\quad$ Defer expenses to meet annual budget (Action 2b) - Accounting majors stricter

- $\quad$ Work overtime to reach budget target (Action $4 b$ ) - Accounting majors stricter

- $\quad$ Bury scrap costs in "other expenses", no income effect (Action 7) - Other majors stricter

\section{Comparison of Our Results with Prior Research Findings}

First, we found that there is a high level of disagreement among the groups of respondents regarding which short-term earnings management practices are ethical. We found that for most of the short-term earnings management practices, females tended to judge the actions less ethical than males judged the actions; undergraduate students generally took a stricter position than business managers; and accounting majors were inclined to view the practices less favorably than other majors. Several prior studies also found disagreement between groups of respondents. For example, Merchant and Rockness (1994) found that general managers were the strictest while internal auditors were the most lenient in their judgments. Rosenzweig and Fischer (1994) found differences when they grouped respondents by years of experience and level of responsibility. Accountants with over six years of experience judged actions less harshly than accountants with six or less years of experience. Similarly, respondents at higher levels (such as partner) were more accepting of practices than respondents at the entry or junior level. Fischer and Rosenzweig (1995) reported that accounting practitioners generally judged actions as less ethical than students judged the actions. Clikeman et al. (2001) found some minor differences in views based on national origin and gender; however, none of the differences were significant. Elias (2002) compared students, faculty, accountants in industry, and accountants in public practice. He reported that accountants in practice (industry and public accounting) were more lenient than accounting students and faculty. In a second study, Elias (2004) found that accountants in organizations with high ethical values judged earnings management actions more harshly than accountants in organizations with low ethical values.

Second, we found that for many of the practices, "qualifiers" affected the respondents' views. Some examples of qualifiers are dollar amount, timing of transaction, the purpose of the practice, the method used, and whether the practice meets quarterly or annual figures.

\section{Dollar Amount}

Actions 8a and 8b illustrate the effect of dollar amount. Both actions involve the request that a supplier defer billing for work done until the next fiscal year so that the division can meet its budget. When the amount involved is $\$ 30,000$ (action 8a) the respondents rated this practice as a "Minor Infraction" with a mean value of 3.1044. However, when the amount is $\$ 500,000$ for the same type of practice, the respondents rated the practice as a "Serious Infraction", with the second-highest mean value (3.8952) of any of the twenty practices. These findings are consistent with those of Bruns and Merchant (1990), Merchant and Rockness (1994), Rosenzweig and Fischer (1994), Fischer and Rosenzweig (1995), Clikeman et al. (2001), and Guffey et al. (2004). These prior studies all reported that materiality was a factor; larger amounts were judged more seriously than smaller amounts.

\section{Timing of Transaction}

Actions 10a through 10d represent a good example of how the timing of the transaction affects the respondents' views. For each action, the situation is the same. The firm is struggling to meet profit targets. The GM tells the production manager to ship some customer orders early so that associated revenues and profits can be recognized in the current year. The goods are in inventory and expected delivery time is two days. Actions 10a through 10d differ only to the extent of these customers' firm delivery dates. Notice that the earlier the accelerated shipment prior to firm delivery date the less ethical the action becomes:

- $\quad$ Action 10a (ship 3 days early): rated by respondents as a "Questionable Practice" (mean value of 2.3984).

- Action 10b (ship 14 days early): rated by respondents as a "Minor Infraction" (mean value 2.9633).

- $\quad$ Action 10c (ship 28 days early): rated by respondents as a "Minor Infraction" (mean value 3.4490).

- $\quad$ Action 10d (ship 42 days early): rated by respondents as a "Serious Infraction" (mean value 3.7306). 


\section{Purpose of the Practice}

Actions $6 \mathrm{a}$ and $6 \mathrm{~b}$ demonstrate how the purpose of the practice affects the respondents' views. When the reduction of the reserve for obsolescence is to enable continued work on some important product development projects that might have to be delayed due to budget constraints, the respondents rate the practice (action 6a) as a "Minor Infraction" (mean value of 2.9073). However, when the purpose of the reduction is to make budgeted profit targets, the respondents take a dimmer view, rating the practice (action 6b) with a mean value of 3.4699. This is consistent with the findings of Merchant and Rockness (1994), Rosenzweig and Fischer (1994), Fischer and Rosenzweig (1995), Clikeman et al. (2001), and Guffey et al. (2004).

\section{Method Used}

An example of how the method used affects the responses relates to practices $4 \mathrm{a}$ through $4 \mathrm{c}$. For each, the GM wants to reach budget targets. Respondents' views are affected by the method used, all to accomplish the same result. We can see that selling excess assets is preferable to working overtime or liberalizing credit terms. Following is a summary of the different ratings for these actions:

- Liberalize credit terms to pull some sales that normally would occur next year into the current year has a mean value of 2.1004 .

- Work overtime so that everything possible could be shipped by the end of the year has a mean value of 1.6747 .

- $\quad$ Sell excess assets and realize profit of $\$ 40,000$ has a mean value of 1.7863 .

Bruns and Merchant (1990), Merchant and Rockness (1994), Rosenzweig and Fischer (1994), Fischer and Rosenzweig (1995), and Clikeman et al. (2001) also all reported that liberalizing credit terms was found less acceptable than working overtime or selling excess assets to increase profits.

\section{Quarterly or Annual Budgets}

Actions $2 \mathrm{a}$ and $2 \mathrm{~b}$ involve deferral of expenses to meet quarterly and annual budgets, respectively. The deferral to meet annual budgets (mean 3.4177) is viewed more negatively than deferral to meet quarterly budgets (mean 2.8760). These findings are consistent with those of prior studies (Bruns and Merchant, 1990; Merchant and Rockness, 1994; Rosenzweig and Fischer, 1994; Fischer and Rosenzweig, 1995; and Clikeman et al., 2001). below.

The averages of the mean responses from prior studies and the mean responses from our study are listed

The means from our study are above the average of prior studies for eight of the 13 actions $(1,2,3,4,5,6$, 7, and 9), indicating that respondents to our study have stricter views than respondents to prior studies for these eight actions. The means from our study are below the average for five actions $(8,10,11,12$, and 13), indicating that respondents to our study are less strict than respondents to prior studies for these five actions. The greatest difference in means is .97 (action 3). The least difference in means is .03 (action 13). Overall, the average rating for all 13 actions for our study was 2.81 . This is not very different from the overall average rating of 2.61 for prior studies, showing that perceptions regarding earnings management have not changed substantially.

The results of this study are consistent with the findings of the Bruns and Merchant study conducted 15 years ago and other prior studies. This would indicate that perceptions regarding earnings management have changed, but they have not changed substantially due to the recent events, such as the issuance of the SarbanesOxley Act of 2002 and failures/frauds including Enron and World Com. 


\begin{tabular}{|c|l|c|c|}
\hline Action & \multicolumn{1}{|c|}{ Description } & Our Study & Average of Prior Studies \\
\hline & $\begin{array}{l}\text { (Action number in parentheses indicates the action number of our study } \\
\text { that corresponds to the action number of prior studies) }\end{array}$ & & \\
\hline & & & \\
\hline 1 & Paint ahead of schedule (Action 1) & 1.43 & 1.18 \\
\hline 2 & Defer expenses to meet quarterly budget (Action 2a) & 2.88 & 2.06 \\
\hline 3 & Defer expenses to meet annual budget (Action 2b) & 3.42 & 2.46 \\
\hline 4 & Defer supplies expense by delaying recording invoice (Action 3) & 3.62 & 3.24 \\
\hline 5 & More liberal credit terms to reach budget target (Action 4a) & 2.10 & 1.93 \\
\hline 6 & Work overtime to reach budget target (Action 4b) & 1.67 & 1.53 \\
\hline 7 & Sell excess assets to reach budget target (Action 4c) & 1.79 & 3.41 \\
\hline 8 & Prepay expenses to reduce income by \$60,000 (Action 5) & 2.76 & 3.07 \\
\hline 9 & Increase reserve for obsolescence; reduce income \$70,000 (Action 5b) & 3.48 & 3.28 \\
\hline 10 & Reduce reserve for obsolescence to continue work (Action 6a) & 2.91 & 3.19 \\
\hline 11 & Reduce reserve for obsolescence to meet budget target (Action 6b) & 3.47 & 3.50 \\
\hline 12 & Request deferred billing from supplier, \$30,000 (Action 8a) & 3.10 & 3.17 \\
\hline 13 & Request deferred billing from supplier, \$500,000 (Action 8b) & 3.90 & \\
\hline & Average rating for study overall & 2.81 & 3.93 \\
\hline
\end{tabular}

Scale: 1-Ethical practice, 2-Questionable practice, 3-Minor infraction, 4-Serious infraction, 5-Totally unethical

\section{IMPLICATIONS FOR ACADEMIA}

The results of our study have implications for academia and, although some of these implications have been identified by prior research, our findings suggest these items are still relevant. As noted above, while there have been some changes in perceptions regarding earnings management, we agree with Fischer and Rosenzweig (1995) that business students need more exposure and understanding of methods used to manage earnings. Business publications should continue to report on a regular basis fraudulent financial reporting that is often the result of earnings management. Fischer and Rosenzweig (1995) suggested that accounting and MBA curricula needed to place a greater emphasis on managers reporting fairly stated financial information in an ethical manner. The difficult issue is to determine where and how this issue should be addressed in the curricula. Whether this is done by integrating ethics into business courses, or requiring a separate business ethics course or an accounting course cotaught by accounting and ethics faculty members, as suggested by Fischer and Rosenzweig (1995) or using a fraud examination course is often debated. Since our findings show that there are some differences between undergraduate students and graduate students (business managers) as well as differences between accounting majors and other business majors we suggest that a capstone (undergraduate and graduate) course, which includes all types of business majors, is an appropriate course to discuss and analyze earnings management. To enhance the "realworld" aspect of this issue, experienced business professionals (for example retired partners of public accounting firms, CEOs, CFOs) should be an integral part of these discussions. To identify such individuals, faculty could solicit alumni of the institution and members of advisory boards or use the executive in residence, if applicable. In addition to providing an experienced business perspective of earnings management, this approach hopefully reduces the likelihood that there will be differences between the accountants and other business majors. As educators we should attempt to minimize those differences because, as Clikeman and Henning (2000, p.13) note, "conflicting opinions begin to develop during undergraduate business education. Students appear to begin adopting the attitudes of their professional reference groups before they even commence their professional careers". If we as educators can use experienced managers and practitioners to enliven and make the discussion of earnings more realistic, then hopefully we can help reduce the expectation gap in this area.

\section{CONCLUSIONS}

Prior to the study by Bruns and Merchant (1990), accounting practitioners and researchers paid little attention to the ethics of earnings management. Since then, there has been increased research regarding the morality of earnings management. The importance of this topic has been recognized in large part because of the highly 
publicized financial failures and frauds, such as Enron and World Com, and subsequent legislation, the SarbanesOxley Act of 2002 (SOX).

Table 1: Tabulation Of Mean Responses From Studies Using The Bruns And Merchant Survey

\begin{tabular}{|c|c|c|c|c|c|c|c|}
\hline Action & Description $^{1}$ & $\begin{array}{l}\text { CURRENT } \\
\text { STUDY } \\
(2005)^{2}\end{array}$ & $\begin{array}{l}\text { Clikeman, } \\
\text { Geiger and } \\
\text { O'Connell } \\
(2001)^{2} \\
\end{array}$ & $\begin{array}{l}\text { Fischer and } \\
\text { Rosenzweig } \\
\quad(1995)^{3}\end{array}$ & $\begin{array}{l}\text { Rosenzweig } \\
\text { and Fischer } \\
\qquad(1994)^{3}\end{array}$ & \begin{tabular}{|c|} 
Merchant and \\
Rockness (1994)
\end{tabular} & $\begin{array}{l}\text { Average of } \\
\text { Prior } \\
\text { Studies }\end{array}$ \\
\hline 1 & Paint ahead of schedule (1) & 1.43 & 1.09 & 1.20 & 1.18 & 1.26 & 1.18 \\
\hline 2 & $\begin{array}{l}\text { Defer expenses to meet quarterly } \\
\text { budget }(2 a)\end{array}$ & 2.88 & 2.81 & 1.98 & 1.62 & 1.81 & 2.06 \\
\hline 3 & $\begin{array}{l}\text { Defer expenses to meet annual } \\
\text { budget }(2 \mathrm{~b})\end{array}$ & 3.42 & 3.56 & 2.29 & 1.88 & 2.09 & 2.46 \\
\hline 4 & $\begin{array}{l}\text { Defer supplies expense by delaying } \\
\text { recording invoice (3) }\end{array}$ & 3.62 & 2.96 & 3.27 & 3.29 & 3.42 & 3.24 \\
\hline 5 & $\begin{array}{l}\text { More liberal credit terms to reach } \\
\text { budget target (4a) }\end{array}$ & 2.10 & 2.24 & 1.70 & 1.81 & 1.96 & 1.93 \\
\hline 6 & $\begin{array}{l}\text { Work overtime to reach budget target } \\
(4 \mathrm{~b})\end{array}$ & 1.67 & 2.08 & 1.42 & 1.30 & 1.31 & 1.53 \\
\hline 7 & $\begin{array}{l}\text { Sell excess assets to reach budget } \\
\text { target }(4 \mathrm{c})\end{array}$ & 1.79 & 1.73 & 1.41 & 1.25 & 1.25 & 1.41 \\
\hline 8 & $\begin{array}{l}\text { Prepay expenses to reduce income by } \\
\$ 60,000(5)\end{array}$ & 2.76 & 2.76 & 2.96 & 3.27 & 3.27 & 3.07 \\
\hline 9 & $\begin{array}{l}\text { Increase reserve for obsolescence; } \\
\text { reduce income } \$ 70,000(5 b)\end{array}$ & 3.48 & 3.06 & 3.21 & 3.32 & 3.51 & 3.28 \\
\hline 10 & $\begin{array}{l}\text { Reduce reserve for obsolescence to } \\
\text { continue work (6a) }\end{array}$ & 2.91 & 2.55 & 3.11 & 3.50 & 3.59 & 3.19 \\
\hline 11 & $\begin{array}{l}\text { Reduce reserve for obsolescence to } \\
\text { meet budget target }(6 \mathrm{~b})\end{array}$ & 3.47 & 3.16 & 3.43 & 3.71 & 3.69 & 3.50 \\
\hline 12 & $\begin{array}{l}\text { Request deferred billing from } \\
\text { supplier, } \$ 30,000(8 \mathrm{a})\end{array}$ & 3.10 & 2.79 & 2.89 & 3.24 & 3.76 & 3.17 \\
\hline 13 & $\begin{array}{l}\text { Request deferred billing from } \\
\text { supplier, } \$ 500,000(8 \mathrm{~b})\end{array}$ & 3.90 & 3.76 & 3.75 & 4.15 & 4.05 & 3.93 \\
\hline & Average rating for study & 2.81 & 2.66 & 2.51 & 2.58 & 2.69 & \\
\hline & & 240 & 115 & 500 & 265 & 308 & \\
\hline & Type of respondents & \begin{tabular}{|c|} 
Undergradu \\
ate \\
accounting \\
students, \\
MBA \\
students, \\
Executive \\
MBA \\
students \\
\end{tabular} & $\begin{array}{l}\text { Fourth-year } \\
\text { accounting } \\
\text { students }\end{array}$ & \begin{tabular}{|c|} 
Undergraduate \\
accounting \\
students, MBA \\
students, \\
Management \\
accountants
\end{tabular} & $\begin{array}{c}\text { Management } \\
\text { accountants }\end{array}$ & \begin{tabular}{|c|} 
General \\
managers, \\
Staff \\
managers, \\
Operating- \\
unit \\
controllers, \\
Internal \\
auditors \\
\end{tabular} & \\
\hline \multicolumn{8}{|c|}{$\begin{array}{l}\text { Acton number in parentheses indicates the action number of the current study that corresponds to the action number of prior studies listed in } \\
\text { the table. }\end{array}$} \\
\hline \multicolumn{8}{|c|}{${ }^{2}$ Scale: 1-Ethical practice, 2-Questionable practice, 3-Minor infraction, 4-Serious infraction, 5-Totally unethical } \\
\hline \multicolumn{8}{|c|}{$\begin{array}{l}{ }^{3} \text { Scale: 1-Ethical, 2-Questionable, 3-Moderate, 4-Serious, 5-Totally unethical; (This scale was reversed from original scale to make results } \\
\text { comparable to other studies; Original scale: 0-Totally unethical, 1-Serious, 2-Moderate, 3-Questionable, 4-Ethical) }\end{array}$} \\
\hline $\begin{array}{r}\text { The } \\
(2002), \mathrm{E} \\
\text { Elias }(200\end{array}$ & $\begin{array}{l}\text { following studies that utilize the Brun } \\
\text { lias (2004), and Guffey, McIntyre and } \\
\text { 4) reported on the accounting practitic }\end{array}$ & $\begin{array}{l}\text { is/Merchant s } \\
\text { McMillan }(2 \\
\text { oners and face }\end{array}$ & $\begin{array}{l}\text { rvey are not inc } \\
\text { 4). Elias ( } 200 \\
\text { ty subset of the }\end{array}$ & $\begin{array}{l}\text { Ided in this table } \\
\text { surveyed } 763 \mathrm{ac} \\
002 \text { survey }(583\end{array}$ & $\begin{array}{l}\text { because the me } \\
\text { counting practi } \\
\text { respondents). }\end{array}$ & $\begin{array}{l}\text { eans data are unava } \\
\text { itioners, faculty, an } \\
\text { Guffey, McIntyre a }\end{array}$ & $\begin{array}{l}\text { ilable: Elias } \\
\text { d students. } \\
\text { ind McMillan }\end{array}$ \\
\hline
\end{tabular}


There were several purposes of our study. First, because sufficient time has elapsed since highly publicized cases and the passage of SOX, we anticipated there might be some changes in attitudes toward the ethicality of short-term earnings management. Thus, we used the Bruns-Merchant instrument to compare our findings with the results of prior research that used the same instrument. While our results are similar to prior research findings, the participants of our study were slightly more strict (tended to view items as less ethical) in their views than participants of prior studies. Second, we also wanted to determine if women and men view short-term earnings management practices differently. We found that women tend to have a stricter view on earnings management actions than men, since there are significant differences between men and women for four of the actions. Third, we wanted to compare the views of undergraduates with business managers. Our findings show that undergraduate students tend to be stricter in their views than business managers; however, only two of these differences are significant. Fourth, we wanted to determine if accounting majors differ from nonaccounting majors with respect to the ethics of earnings management practices. Although accounting majors tend to be stricter in their views than other business majors, only two of the differences are significant.

Our study contributes to the literature in three specific ways. First, while our findings provide support for prior research results, there is some evidence of an attitude change (stricter view) regarding the ethics of earnings management actions. Prior research had not examined this issue. . Second, the study finds some gender differences, between-major differences and differences between undergraduates and business managers

This study is subject to limitations. First, although we have no reason to believe otherwise, the students and business managers in our study might not be representative of students and business managers nationally. Second, there are limitations with the use of any survey instrument. For example, the scenarios and the wording of the earnings actions are subject to interpretation. While this is a limitation, we did not change the wording of the instrument in order to enhance comparability with prior research.

\section{Table 2 Questionnaire On Ethics}

This questionnaire includes short descriptions of a variety of actions that individuals have taken. Some of these actions are clearly ethical. Others are judged by some or most people to be unethical, and the judgments as to the degree of severity of the infraction can vary widely.

Please indicate your judgment as to the acceptability of each of the practices using the following scale:

$1=$ Ethical practice

$2=$ Questionable practice. I would not say anything to the person involved, but it makes me uncomfortable.

$3=$ Minor infraction. The person should be warned not to engage in the practice again.

$4=$ Serious infraction. The person should be severely reprimanded.

$5=$ Totally unethical. The person should be fired.

(Assume that the divisions referred to are part of a $\$ 1$ billion corporation, which has a January-December fiscal year. Each division has annual sales of $\$ 100$ million, with annual before-tax operating profit of $\$ 12$ million.)

Answer each question separately. (Assume the incidents are independent.)

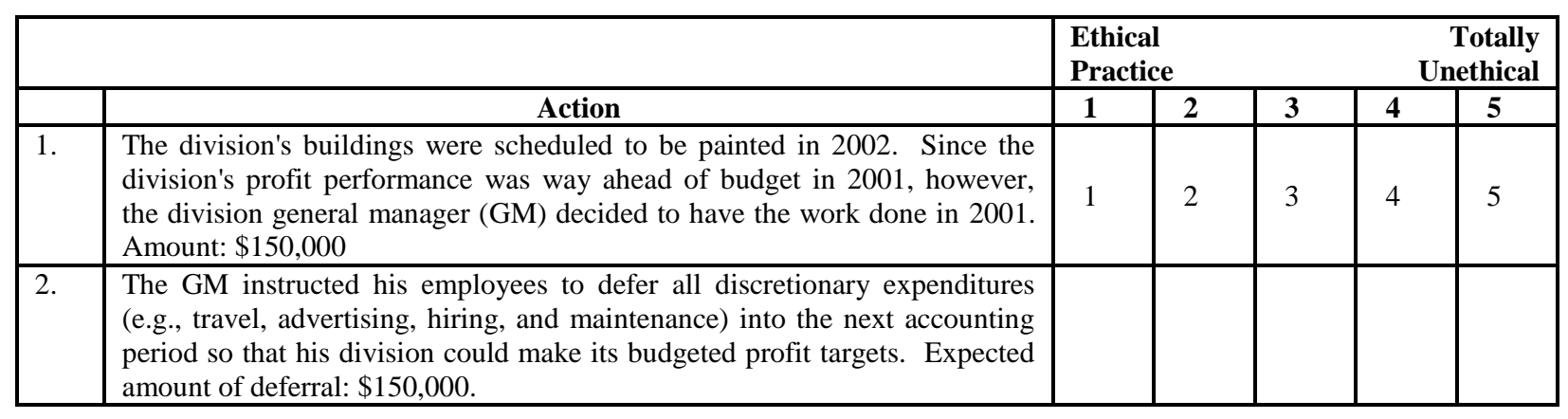




\begin{tabular}{|c|c|c|c|c|c|c|}
\hline & $\begin{array}{l}\text { a. The expenses were postponed from February and March until April in } \\
\text { order to make the first quarter target. }\end{array}$ & 1 & 2 & 3 & 4 & 5 \\
\hline & $\begin{array}{l}\text { b. The expenses were postponed from November and December until } \\
\text { January in order to make the annual target }\end{array}$ & 1 & & 3 & 4 & 5 \\
\hline 3. & $\begin{array}{l}\text { On December } 15 \text {, a clerk in the division placed an order for } \$ 3,000 \text { worth of } \\
\text { office supplies and the supplies were delivered on December } 29 \text {. This order } \\
\text { was a mistake because the division GM had ordered that no discretionary } \\
\text { expenses be incurred for the remainder of the fiscal year, and the accounting } \\
\text { policy manual states that office supplies are to be recorded as an expense } \\
\text { when delivered. The division GM learned what had happened, however, and } \\
\text { to correct the mistake, he ordered the accounting department not to record } \\
\text { the invoice until February. }\end{array}$ & 1 & 2 & 3 & 4 & 5 \\
\hline \multirow[t]{4}{*}{4.} & $\begin{array}{l}\text { In September, a GM realized that the division would need strong } \\
\text { performance in the last quarter of the year in order to reach its budget } \\
\text { targets. }\end{array}$ & & & & & \\
\hline & $\begin{array}{l}\text { a. He decided to implement a sales program offering liberal payment } \\
\text { terms to pull some sales that would normally occur next year into the } \\
\text { current year; customers accepting delivery in the } 4 \text { th quarter would not } \\
\text { have to pay the invoice for } 120 \text { days. }\end{array}$ & 1 & 2 & 3 & 4 & 5 \\
\hline & $\begin{array}{l}\text { b. He instructed manufacturing to work overtime in December so that } \\
\text { everything possible could be shipped by the end of the year }\end{array}$ & 1 & 2 & 3 & 4 & 5 \\
\hline & c. He sold some excess assets and realized profit of $\$ 40,000 \ldots \ldots$ & 1 & 2 & 3 & 4 & 5 \\
\hline \multirow[t]{3}{*}{5.} & $\begin{array}{l}\text { At the beginning of December, 2001, a GM realized that the division would } \\
\text { exceed its budgeted profit targets for the year. }\end{array}$ & & & & & \\
\hline & $\begin{array}{l}\text { a. He ordered his controller to prepay some expenses (e.g., hotel rooms, } \\
\text { exhibit expense) for a major trade show to be held in March } 2002 \text { and to } \\
\text { book them as } 2001 \text { expense. Amount: } \$ 60,000\end{array}$ & 1 & 2 & 3 & 4 & 5 \\
\hline & $\begin{array}{l}\text { b. He ordered his controller to develop the rationale for increasing the } \\
\text { reserve for inventory obsolescence. By taking a pessimistic view of } \\
\text { future market prospects, the controller was able to identify } \$ 700,000 \\
\text { worth of finished goods that conservative accounting would say should } \\
\text { be fully reserved (i.e., written off), even though the GM was fairly } \\
\text { confident the inventory would still be sold at a later data at close to full } \\
\text { price. }\end{array}$ & 1 & 2 & 3 & 4 & 5 \\
\hline \multirow[t]{3}{*}{6.} & $\begin{array}{l}\text { The next year, the division described in question } 5 b \text { sold } 70 \% \text { of the written- } \\
\text { off inventory, and a customer had indicated some interest in buying the rest } \\
\text { of that inventory the following year. The GM ordered his controller to } \\
\text { prepare the rationale for reducing the reserve for obsolescence by } \$ 210,000 \\
\text { (i.e., writing up the previously written-off goods to full cost). The GM's } \\
\text { motivation for recapturing the profit was: }\end{array}$ & & & & & \\
\hline & $\begin{array}{l}\text { a. to be able to continue working on some important product } \\
\text { development projects that might have had to be delayed due to budget } \\
\text { constraints }\end{array}$ & 1 & 2 & 3 & 4 & $\overline{5}$ \\
\hline & b. to make budgeted profit targets & 1 & 2 & 3 & 4 & 5 \\
\hline 7. & $\begin{array}{l}\text { In July, 2002, a GM noticed that scrap costs in the plant were running way } \\
\text { ahead of plan. So that senior management would not become alarmed, he } \\
\text { instructed his controller to "bury" most of the scrap costs in other expense } \\
\text { accounts where they would not be noticed. Over the remainder of the year, } \\
\text { the controller buried approximately } \$ 60,000 \text { of scrap costs. Effect on net } \\
\text { income: zero }\end{array}$ & 1 & 2 & 3 & 4 & $\overline{5}$ \\
\hline \multirow[t]{3}{*}{8.} & $\begin{array}{l}\text { In November 2001, a division was straining to meet budget. The GM called } \\
\text { the engagement partner of a consulting firm that was doing some work for } \\
\text { the division and asked that the firm not send an invoice for work done until } \\
\text { the next fiscal year. The partner agreed. Estimated work done but not } \\
\text { invoiced: }\end{array}$ & & & & & \\
\hline & a. $\$ 30,000$ & 1 & 2 & 3 & 4 & 5 \\
\hline & b. $\$ 500,000$ & 1 & 2 & 3 & 4 & 5 \\
\hline 9. & A GM had an idea for a new product. She asked her marketing people to & & & & & \\
\hline
\end{tabular}




\begin{tabular}{|c|c|c|c|c|c|c|}
\hline & $\begin{array}{l}\text { conduct some focus group interviews and a field study to determine the } \\
\text { market potential, and she asked her controller to estimate the costs of } \\
\text { entering the market. The projections promised only a } 22 \% \text { return when the } \\
\text { desired return for his business was } 35 \% \text {. However, still convinced that the } \\
\text { product was a good idea, the manager "jacked up" the sales projections and } \\
\text { "shaved" the cost estimates to show a forecasted } 35 \% \text { return. The GM's } \\
\text { superiors were preoccupied with other problems, and they did not question } \\
\text { the projections. Thus the new product was approved. }\end{array}$ & & & & & \\
\hline & a. After six months of sales, the product earned a $22 \%$ return. & 1 & 2 & 3 & 4 & 5 \\
\hline & b. After six months of sales, the product earned a 35\% return. & 1 & 2 & 3 & 4 & 5 \\
\hline 10. & $\begin{array}{l}\text { At the end of December, a division was struggling to meet its profit targets. } \\
\text { The GM told his production manager to ship some customer orders early so } \\
\text { that the associated revenue and profits could be recognized in the current } \\
\text { year. The items were in inventory, and expected delivery times were two } \\
\text { days. The customers' firm delivery dates were: }\end{array}$ & & & & & \\
\hline & a. January 3 & 1 & 2 & 3 & 4 & 5 \\
\hline & b. January 14 & 1 & 2 & 3 & 4 & 5 \\
\hline & c. January 28 & 1 & 2 & 3 & 4 & 5 \\
\hline & d. February 12 & 1 & 2 & 3 & 4 & 5 \\
\hline
\end{tabular}

DEMOGRAPHICS: Gender: Female ___ Male Major: $\mathrm{ACCO}_{\_}$FINA __ Other (Specify)

Table 3: How Respondents Rated Earnings Management Actions

$\frac{\text { Ethical Categories }}{\text { Totally Unacceptable }}$

Serious Infraction

Minor Infraction

\section{Questionable}

Ethical

\section{$\underline{\text { Description (Action Number) }}$} None $\underline{\text { Mean }}$

3.9153

3.8952

3.7409

3.7306

3.6200

3.4699

3.4760

3.4490

3.4177

3.3887

3.1044

2.9633

2.9073

2.8760

2.7640

2.3984

2.1004

1.7863

1.6747

1.4297 $\underline{\text { Std Dev }}$

0.9247

1.0324

0.9865

1.0207

0.9461

1.0081

0.9906

1.0053

1.2124

1.0720

1.0304

1.0687

1.0433

1.1427

1.2371

1.1302

1.0785

0.9601

0.8768

0.8449 
Table 4: Responses By Gender, Level, And Major Mean Value And Significant Differences (T-Test)

\begin{tabular}{|c|c|c|c|c|c|c|c|c|c|}
\hline \multirow[b]{3}{*}{ Action } & \multicolumn{9}{|c|}{ Mean Values } \\
\hline & \multicolumn{3}{|c|}{ Gender } & \multicolumn{3}{|c|}{ Level } & \multicolumn{3}{|c|}{ Major } \\
\hline & $\mathrm{F}$ & $\mathrm{M}$ & & $\mathrm{UG}$ & Bus & & Acco & Other & \\
\hline 1. Paint ahead of schedule & 1.49 & 1.39 & & 1.41 & 1.46 & & 1.39 & 1.42 & \\
\hline 2(a). Defer expenses to meet quarterly budget & 3.08 & 2.78 & & 3.02 & 2.69 & $*$ & 2.97 & 2.82 & \\
\hline 2(b). Defer expenses to meet annual budget & 3.76 & 3.25 & $*$ & 3.65 & 3.11 & $*$ & 3.61 & 3.27 & * \\
\hline 3. Defer supplies expense by delaying recording invoice & 3.65 & 3.62 & & 3.69 & 3.53 & & 3.71 & 3.59 & \\
\hline 4(a). More liberal credit terms to reach budget target & 2.14 & 2.08 & & 2.04 & 2.18 & & 2.15 & 2.07 & \\
\hline 4(b). Work overtime to reach budget target & 1.92 & 1.57 & $*$ & 1.76 & 1.56 & & 1.84 & 1.57 & * \\
\hline 4(c). Sell excess assets to reach budget target & 1.88 & 1.74 & & 1.80 & 1.77 & & 1.84 & 1.75 & \\
\hline 5(a). Prepay expenses to reduce income by $\$ 60,000$ & 2.83 & 2.73 & & 2.75 & 2.78 & & 2.77 & 2.75 & \\
\hline 5(b). Increase reserve for obsolescence; reduce income $\$ 700,000$ & 3.52 & 3.44 & & 3.40 & 3.57 & & 3.47 & 3.43 & \\
\hline 6(a). Reduce reserve for obsolescence to continue work & 2.96 & 2.89 & & 2.83 & 3.01 & & 2.88 & 2.91 & \\
\hline 6(b). Reduce reserve for obsolescence to meet budget target & 3.53 & 3.44 & & 3.48 & 3.45 & & 3.48 & 3.46 & \\
\hline 7. Bury scrap costs in "other expenses", no income effect & 3.97 & 3.88 & & 3.82 & 4.04 & & 3.76 & 4.05 & $*$ \\
\hline $8(\mathrm{a})$. Request deferred billing from supplier, $\$ 30,000$ & 3.17 & 3.07 & & 3.16 & 3.04 & & 3.14 & 3.09 & \\
\hline $8(\mathrm{~b})$. Request deferred billing from supplier, $\$ 500,000$ & 4.18 & 3.76 & $*$ & 4.00 & 3.76 & & 3.99 & 3.81 & \\
\hline 9(a). Raise return forecast from $22 \%$ to $35 \%$, actual $22 \%$ & 3.70 & 3.75 & & 3.67 & 3.83 & & 3.74 & 3.73 & \\
\hline 9(b). Raise return forecast from $22 \%$ to $35 \%$, actual $35 \%$ & 3.20 & 3.48 & $*$ & 3.30 & 3.44 & & 3.30 & 3.45 & \\
\hline 10(a). Accelerate delivery to customer by 3 days & 2.43 & 2.39 & & 2.42 & 2.37 & & 2.37 & 2.45 & \\
\hline 10(b). Accelerate delivery to customer by 16 days & 3.04 & 2.93 & & 3.01 & 2.91 & & 2.96 & 2.97 & \\
\hline 10 (c). Accelerate delivery to customer by 28 days & 3.51 & 3.42 & & 3.49 & 3.39 & & 3.48 & 3.42 & \\
\hline 10(d). Accelerate delivery to customers by 42 days & 3.91 & 3.65 & & 3.81 & 3.63 & & 3.82 & 3.65 & \\
\hline
\end{tabular}

\section{REFERENCES}

1. Akaah, I. 1989. Differences in Research Ethics Judgments Between Male and Female Marketing Professionals. Journal of Business Ethics 8: 375-381.

2. Akers, M. D. and T.V. Eaton. 2003. Underreporting of Chargeable Time. Journal of Managerial Issues 15(1): 82-96.

3. $\quad$ Akers, M.D. and D.E. Giacomino.1999. Personal Values of Certified Auditors. Internal Auditing 14(1): 1927.

4. Akers, M.D. and D.E. Giacomino. 2000. Ethics and the Accountants' Code of Conduct. The Journal of Applied Business Research 16 (3): 87-95.

5. Altamuro, J., A. Beatty, and J. Weber. 2005. The effects of accelerated revenue recognition on earnings management and earnings informativeness: Evidence from SEC Staff Accounting Bulletin No. 101. The Accounting Review 80(2): 373-401.

6. Beltramini, R., R. Peterson, and G. Kozmetsky. 1984. Concerns of College Students Regarding Business Ethics. Journal of Business Ethics 3: 195-200.

7. Bruns, W. and K. Merchant. 1990. The dangerous morality of managing earnings. Management Accounting 72(2): 22-25.

8. Cheng, Q. and T. Warfield. 2005. Equity incentives and earnings management. The Accounting Review 80(2): 441-476.

9. Clikeman, P. and S. Henning. 2000. The socialization of undergraduate accounting students. Issues in Accounting Education 15(1): 1-17.

10. ----, M. Geiger and B. O'Connell. 2001. Student perceptions of earnings management: The effects of national origin and gender. Teaching Business Ethics 5(4): 389-410.

11. Cohen, J., L.W. Pant, and D. D. Sharp. 1998. The Effect of Gender and Academic Discipline Diversity on the Ethical Evaluations, Ethical Intentions and Ethical Orientation of Potential Public Accounting Recruits. Accounting Horizons September: 250-270. 
12. Eaton, T.V. and D.E. Giacomino. 2000. Personal Values of Business Students: Differences by Gender and Discipline. Research on Accounting Ethics 5: 83-102.

13. Elias, R. 2002. Determinants of earnings management ethics among accountants. Journal of Business Ethics 40(1): 33-45.

14. ---. 2004. The impact of corporate ethical values on perceptions of earnings management. Managerial Auditing Journal 19(1): 84-98.

15. Fagenson, E. A. 1993. Personal Value Systems of Men and Women Entrepreneurs Versus Managers. Journal Business Venturing 8: 409-430.

16. Fischer, M. and K. Rosenzweig. 1995. Attitudes of students and accounting practitioners concerning the ethical acceptability of earnings management. Journal of Business Ethics 14(6): 433-444.

17. Giacomino, D.E. and M.D. Akers. 1998. An Examination of the Differences Between Personal Values and Value Types of Female and Male Accounting and Nonaccounting Majors. Issues in Accounting Education 13(3): 565-584.

18. Guffey, D., D. McIntyre, and J. McMillan. 2004. Measuring and influencing students' ethical and professional perceptions of earnings management. Proceedings of the 2004 College Teaching \& Learning Conference.

19. Jones, T.M. and F. H. Gautschi III. 1998. Will the Ethics of Business Change? A Survey of Future Executives. Journal of Business Ethics 7(4): 231-248.

20. Kaplan, S. 2001. Ethically related judgments of observers of earnings management. Journal of Business Ethics 32(4): 285-298.

21. Kim, J., R. Chung, and M. Firth. 2003. Auditor conservatism, asymmetric monitoring, and earnings management. Contemporary Accounting Research 20(2): 323-359.

22. Marquardt, C. and C. Wiedman. 2004. How are earnings managed? An examination of specific accruals. Contemporary Accounting Research 21(2): 461-489.

23. Merchant, K. and J. Rockness. 1994. The ethics of managing earnings: An empirical investigation. Journal of Accounting and Public Policy 13: 79-94.

24. Peterson, R.A., R. P. Beltramini, and G. Kozmetsky. 1991. Concerns of College of Students Regarding Business Ethics: A Replication. Journal of Business Ethics 10: 733-738.

25. Rosenzweig, K. and M. Fischer. 1994. Is managing earnings ethically acceptable? Management Accounting 75(9): 31-34.

26. Sweeney, J. 1995. The Moral Expertise of Auditors: An Exploratory Analysis. Research on Accounting Ethics 1: 213-234. 